\title{
Investigating the Effects of Sociodemographic Characteristics on Psychological Factors That Impact on Educational Process of Adult Learners in Second Chance Schools in Greece
}

\author{
Georgia Karakitsiou, ${ }^{1}$ Anna Tsiakiri ${ }^{1} \&$ Katerina Kedraka ${ }^{1,2}$ \\ ${ }^{1}$ Democritus University of Thrace, Thrace, Greece \\ ${ }^{2}$ Hellenic Open University, Patra, Greece \\ Correspondence: Karakitsiou Georgia, Democritus University of Thrace, Thrace, Greece.
}

Received: April 20, 2021 Accepted: May 13, 2021 Online Published: May 18, 2021

doi:10.5539/res.v13n2p122 URL: https://doi.org/10.5539/res.v13n2p122

\begin{abstract}
The present study deals with the influence of various psychological factors faced by adults during the educational process at Second Chance Schools in Greece. We studied how the feelings of shame, anxiety and depression were associated with the demographic characteristics of the adult learners of these schools. Ninety-five trainees took part in the research whose results indicated that socio-demographic characteristics have an impact on psychological factors that can contribute to the educational process of adult learners.

Sex and marital status were related to the feeling of shame (especially the body shame) and this may be an inhibitory factor to initial integration in or continuation with the studies in SCSs. Single and employed individuals were less vulnerable to development of depression and anxiety disorders, which has been found to have a negative effect on academic achievement. Based on such aspects, counseling approaches and interventions could be designed and implemented by Counselors Psychologists to improve the counseling services provided by the SCSs.
\end{abstract}

Keywords: adult learners, Second Chance Schools (SCSs), shame, anxiety, depression, educational process

\section{Introduction}

\section{The operating framework of Second Chance Schools in Greece and globally}

Second Chance Schools were set up following a proposal by the European Commission for Education and Training. They aim to reduce the social and educational exclusion of disadvantaged young people (European Commission, 1996). In Greece, Second Chance Schools were enacted by Law 2525/97 (Government Gazette 188/1997); they aim to enroll young people aged above 18 years and have not completed the Compulsory Nine-Year Education.

Second Chance Schools (SCS) in Greece are governed by three basic operating principles: flexibility in the use of the teaching aids, support provided to trainees in general and being run by staff who have undergone in-depth scientific training. In these schools, their educational process encourages cooperation with and joint actions with other bodies, cultivation of social skills, emphasis on the acquisition of new knowledge and development of a flexible curriculum. Second Chance Schoolos attain these principles by focusing on the individual profile of each trainee (Government Gazette 1861/2014).

Second Chance Schools are located throughout the European Union. France was the first country to establish and operate SCSs in 1997 which then served as a model for the establishment of many SCSs throughout Europe. However, these schools' frameworks are not identical in all countries, several factors (political, economic, social) influence the operation of these schools (Arico \& Lasselle, 2010).

Many countries then implemented Second Chance School pilot programs. By 2000, the number of SCSs in the European Union exceeded 300. Among the EU countries that established such schools are England, Spain, Germany and Italy. Outside the European Union, countries such as Algeria, Argentina, Brazil, Australia, Romania and Tunisia also established SCSs (Stoilescu \& Carapanait, 2011; Ross \& Gray, 2005).

In countries where the specific school frameworks have been established, they operate differently. They are tailored to different target groups and use different educational practices in each case, all of them move under a main axis. Second Chance Schools, all over the word move under a main axis. They are used as levers to integrate marginalized people into mainstream society (Margara \& Anagnou, 2008). 
In all Second Chance Schools worldwide, their initial goal is to reconnect with educational systems while their ultimate goal is to combat unemployment and marginalization (European Commission, 2001). Many studies conducted in the literature show that to a large extent, the primary goal of Second Chance Schools has been largely achieved (Smyth \&Hattam, 2004; Wyn, Stokes, \& Tyler, 2004; TeRiele, 2000).

Second Chance Schools are also seen as an additional opportunity for people who due to having experienced school failure, face social and emotional isolation and exclusion (Munns \& McFadden, 2000). Numerous studies show that SCS structures significantly contribute to strengthening of "social capital" (Ross \& Gray, 2005).

In Greece, the basic principles of Adult Education have been applied in Second Chance Schools (Kokkos, 2005). Additionally, transformative learning is employed to address the dysfunctional and stereotypical perceptions in which a person is trapped in during his lifetime (Kokkos, 2017; Mezirow et al., 2007). Another very crucial innovation in SCS structures is that they are transformed from places of "knowledge transfer" to places of "knowledge production" (Vergidis, 2003). This transformative process is attained by the use of an open and flexible curriculum (Vergidou, Vergidis, \& Ifanti, 2018).

The in-depth study of issues related to lifelong education is extremely important to all societies. This is especially so where research addresses the impact of education among vulnerable groups and how to facilitate educational process for such groups. Lifelong learning aids in completion of the basic compulsory education, the reconnection of its trainees to educational systems, participants' social and economic development, enhancing participants self-esteem and the improvement of their position in the workplace (Asimaki, Kiriazopoulou, \& Vergidis, 2016; Vergidis et al., 2007; Vergidis $\&$ Prokou, 2005). By completing their education, the trainees are expected to significantly improve their cooperation, problem-solving ability, initiative and synthetic skills (Marmarinos, Sakellari, \& Tzoumaka, 2008; Glaroudi \& Katsani, 2008). An investigation into the factors that interfere or facilitate educational process in specific educational contexts will provide knowledge that can improve SCS and the social and economical status of the adult learners.

\section{Theoretical perspectives}

\section{Empowerment through the educational process}

Adult Education, as a scientific field, can serve as a starting point for human development worldwide (Kasworm, Rose, \& Ross-Gordon,2010). The process of Adult Education develops active citizens in the society who are informed about a variety of issues as shown by the Hamburg Declaration. In Greece, basic education is defined as the successful completion of kindergarten, primary and secondary school. Basic education should be an inalienable right for all citizens globally regardless of age, gender, origin, and nationality. Therefore, Adult Education should be given as much attention as that given to the education of minors (Unesco, 1997).

Among persons who have not completed basic education, empowerment can be attained through undergoing Adult Education (Leve, 2001). Learners are empowered by the acquiring basic skills, undergoing training, by using the transformative theory of learning and promoting critical thinking (Papaioannou \& Gravani, 2018). Through education, adult learners undergo fundamental structural changes and significantly expand their horizons, so that they can successfully cope with everyday challenges (Merizow, 1991).

Specifically, empowerment occurs when education is provided to marginalized populations (Apple, 2004). In the sector of Adult Education, it is found that adult learners feel more empowered on an interpersonal and personal level after completing educational programs (Prins, 2008). Thus, education can be used as a tool to address the social exclusion of socially vulnerable groups (Kump \& Krasovec, 2007; Bowman \& Burden, 2002).

\section{The experience of shame}

The concept of shame refers to an individual's acceptance of the existence of a "defective self" (Tangney \& Dearing, 2002). According to Lewis, the person who is ashamed has the need to hide from his environment, feels angry, uncomfortable, worthlessness and inadequate finally completely personifies these thoughts such that he loses his ability to think and act in a healthy manner. (Lewis, 2003).Generally, shame is a painful emotion and the person experiencing shame feels like he has committed an immoral, dishonest or inadmissible act (Lewis, 1971).

Shame is fundamental in self and the social development of the individual as it largely impacts on his or her psychological adaptation to various conditions (Mills, 2005). There appears to be a correlation between shame and psychopathology, however, the exact interaction between the two factors has not been clarified to date (Andrews et al., 2002). Furthermore, high levels of shame can negatively affect not only an indvidual's mental development but also his or her physical development (Kemeny, Gruenewald, \& Dickerson, 2004). A study by Bosma and his colleagues found a positive correlation between low educational attainment and feelings of social inadequacy and shame. People who had attained at lower levels of educational reported more intense feelings of shame when compared to people with higher levels of education (Bosma et al., 2014). 


\section{Depression}

Depression is a mood disorder that significantly affects the functionality of the individual in many areas of everyday life (American Psychological Association, 2013). According to the World Health Organization, depression is a contributor to dysfunction worldwide: two hundred and sixty-four million people of all ages around the world suffer from depression. Women are more likely have depression when compared to men and severe form of this disease can lead to suicide (World Health Organization, 2020). Depression can significantly affect the psychosocial dimension of human existence, especially if it is not detected and treated in a timely manner (Lecrubier, 2001).

The degree and direction of the relationship between education and depression has already been established and investigated for decades (Dohrenwend et al., 1992: Holzer et al., 1986: Adler et al., 1994). Research that has taken place clearly shows a positive correlation between low educational attainment and depression in adulthood (Miech \& Shanahan, 2000).

\section{Anxiety}

Anxiety is a feeling that most people experience or have experienced especially in this day. In many cases, this feeling, depending on its intensity, may be a driving force for an immense serious decrease in an individual's functionality (Horwitz, 2013; Atif et al., 2016).

The transition from simple stress to the onset of an anxiety disorder occurs when the subjective feeling experienced is intense and disproportionate its cause and it impact a person's daily functionality. Anxiety disorders are the most common mental illnesses (Kessler et al., 2005 \& Quilty et al., 2003).

The exact relationship between a low level of education and anxiety has not been established (Bjellant et al., 2008). However, research data shows strong evidence that people without a completed basic education experience higher levels of anxiety when compared to those with a higher level of education (Miech et al., 1999: Andrews et al., 2001).

The main research questions include:

- Do the trainees of Second Change Schools in Greece experience feelings of shame based on to their socio-demograpic characteristics?

- Do the trainees of Second Change Schools in Greece experience feelings of depression based on to their socio-demograpic characteristics?

- Do the trainees of Second Change Schools in Greece experience anxiety disorders based on to their socio-demographic characteristics?

\section{Method}

A request to conduct of the research submitted by the research team was approved by the Ministry of Education, General Secretariat for Lifelong Learning, Directorate for Lifelong Learning, and the Department of Curriculum and Study Programs. Consent was also sought from the Directors of both SCSs before informing potential participants about the research purposes and processes.

The participants were all SCSs trainees selected based on the following eligibility criteria: a) aged > 18 years, b) an ability to speak and understand the Greek language and c) voluntary participation in the study.

Data collection was done using four different data collection tools:

Demographic data questionnaire: this collected information about age, gender, religious beliefs, marital and occupational status.

Experience of Shame Scale-ESS (Andrews B., Qian M., Valentine J. D., 2002).

The ESS is a self-reported questionnaire derived from a semi-structured interview. It enquires whether an interviewee has felt ashamed of his or her specific personal characteristics and behavior (Andrews \& Hunter, 1997). It measures a person's tendency to feel ashamed and not to feel guilty. It evaluates shame as a dispositional characteristic and not as a response to specific situations. It consists of 25 items which are rated in a 4-point scale. The items are divided into three subscales: characterological shame, behavioral shame and bodily shame which are scored separately. The scores for each sub scale are then summed up to a total score: higher scores indicate more frequent and/or more intense experiences of shame.

\section{Patient Health Questionnaire - 9 (PHQ-9).}

PHQ, a self-administered questionnaire developed on the basis of the clinician-administered Primary Care Evaluation of Mental Disorders (PRIME-MD) (Spitzer, 1994), was translated to the Greek language by Karekla et al. (2012). The PHQ-9 is a 9-item depression module adapted from the full PHQ that is used to diagnose major depression. Respondents 
answered nine questions based on a four-point scale, and the sum of the scores can detect zero, mild, moderate or even major depressive disorder. It has been validated for use in primary care (Cameron et al., 2008) and can be used to make a tentative diagnosis of depression in at-risk populations. It will be necessary to emphasize that for reasons of securing the licensing in order to conduct the investigation and according to the instructions of the Ministry of Education it was necessary to modify the questions that investigated the suicidal tendencies of the participants, so as not to raise such personal and sensitive issues.

\section{The State-Trait Anxiety Inventory (STAI) (Spielberger et al., 1983).}

The STAI is a commonly used measure of trait and state anxiety. It is used in clinical settings to diagnose anxiety and to distinguish anxiety from depressive syndromes. It is often used in research as an indicator of caregiver distress (Greene et al., 2017, Ugalde et al., 2014). It consists of 20 items that assess trait anxiety and 20 items that assess state anxiety. All items are rated on a 4-point scale with higher scores indicating greater anxiety.

Printed questionnaires were administered to the SCSs trainees at the beginning of May 2019 who after obtaining written informed consent to participate in the research by the Counselor Psychologist at each SCS. Each individual session lasted 30-45 minutes.

There were no interventions used or experimental manipulations done.

\section{Reliability of data collection tools}

Reliability indicates stability between different successive measurements assessed using the same tool. The reliability of internal consistency or coherence assesses the degree to which a measuring instrument is homogeneous. This assessment was made using the Cronbach's index; values greater than 0.7 are considered satisfactory (Ouzouni \& Nakakis, 2011). The Cronbach's Scale for the Experience of Shame scale was 0.808 on both the overall and individual scales of this questionnaire (Table 1).

Cronbach's score for the Spielberger State Trait Anxiety Inventory was 0.889 on both the overall and individual scales of this questionnaire (Table 2). Finally, Cronbach's Alpha in the Patient Health Questionnaire-9 (PHQ-9) was 0,853 (Table 3).

\section{Data analysis}

Research results were recorded in a worksheet in the SPSS statistical package for statistical analysis. We assessed for correlations between the factors gender, age, religion, marital and professional status and scores in both the individual scales and in the overall shame scores.

The existence or non-existence of an association between the scores of the PHQ-9 scale (Patient Health Questionnaire-9) and the factors gender, age, religion, marital and professional status was also assessed.

The correlations between the total and the individual stress scales in the Spielberger Stress Questionnaire and participants characteristics were also evaluated.

\section{Results}

\section{Participant characteristics}

The study sample was comprised of 95 SCSs trainees from two different districts in Northern Greece; 49 people were male and 46 were female. Among them, 37.9\% (46) were aged 18-34 years, 49.5\% (47) were aged 35-50 years, while the rest $12.6 \%$ (12 persons) were aged more than 50 years. Most of the participants were married with children (53.7\%;51), $22.1 \%$ (21) were single, $12.6 \%$ (12) were divorced, 8.4\% (8) were married without children and 3.2\% (3) were widowed.

As regards their professional status, $42.1 \%$ (40) were unemployed, 37.9\% (36) were employed in the private sector, $10.5 \%$ (10) were employed in the public sector, $6.3 \%$ (6) were retired and 3.2\% (3) were unable to work as they had a disability certificate from Governmental Disability Certification Centers (Table 4).

\section{The Experience of Shame Scale (ESS)}

The table number 5 presents the range of values, the average, the standard deviation and the median value for the three different types of shame: characterological shame, behavioral shame, and bodily shame, and the total score of the Scale for the Experience of (Table 5).

A highly positive and statistically significant correlation was found at a significance level of 0.01 between the gender and physical shame $(r=0.27)$. Women felt higher levels of physical shame when compared to men. A participant's marital status was highly negatively correlated with the overall experience of shame $(\mathrm{r}=-0.21)$ and with the characteristic shame $(\mathrm{r}=-0.21)$; this was statistically significant. People who were divorced, unmarried or widowed experienced lower levels of shame (both characteristically and overall) when compared to married people with or without children. There was no correlation observed between other participant characteristics and shame (Table 6). 


\section{Depression as measured by the Patient Health Questionnaire-9 (PHQ-9) scale}

Finally, the depression factor was assessed with the Patient Health Questionnaire-9 (PHQ-9) scale. The table number 7 presents the range of values, the average, the standard deviation and the median value for each of the 9 items measured on a 4-point scale separately and the total score (Table 7).

A highly negative and statistically significant correlation was found between of marital status $(r=-0.24)$ and occupational status $(\mathrm{r}=-0.23)$ and the depression score; this was at a significance level of 0.05 . People with fewer family responsibilities had lower levels of depression compared to those with more family responsibilities. Moreover, workers had lower rates of depression when compared to participants who were unemployed (Table 8).

\section{The Spielberger State Trait Anxiety Inventory}

The table number 9 presents the range of values, the average, the standard deviation and the median value for firstly State Anxiety which refers to transient anxiety and secondly trait anxiety which refers to the stress experienced by the individual as a permanent condition and for the total score of the Scale for the Experience of Shame (Table 9).

Highly negative and statistically significant correlations were observed between both transient $(r=-0.26)$ and permanent stress $(r=-0.26)$ and marital status (at a significance level of 0.05$)$. Furthermore, a highly negative and statistically significant correlation between the overall stress score and marital status $(r=-0.28)$ was observed (in significance level 0.01). It appears that people with fewer family responsibilities experienced lower levels of stress (transient, permanent, and overall) when compared to people with more family responsibilities.

Furthermore, highly negative and statistically significant correlations were identified at a significance level of 0.05 between both permanent $(r=-0.25)$ and total stress $(r=-0.23)$ and occupational status. Analyzing the above, it seems that rehabilitated people experience lower levels of total and permanent stress compared to the unemployed (Table 10).

Age and religion were not correlated with any of the factors under investigation. More specifically, there were no correlations between age or religion and shame, depression or anxiety.

\section{Discussion}

This study illustrated the effect of socio-demographic characteristics on psychological factors which could contribute to educational process experienced adult learners. A participant's gender was related to the feeling of shame: this may be an obstacle to initial integration in or continuation with studies at an SCSs. Based on the typology of barriers to studying in Adult Education proposed by Cross (1981), these barriers are categorised into three groups: situational, institutional, and dispositional. The feeling of shame could be described as a dispositional obstacle, i.e., those related to the perceptions created in learners about their ability to complete the training. On the other hand, family burdens are a typical situational barrier that describes difficulties faced by an adult at a certain period of his life that affect his availability to participate in educational activities. This finding concurs with Rubenson and Desjardins (2009) who showed that situational barriers were more common in women. The participation of individuals in educational programs in the adult phase of their lives may be limited - among other things - by individual characteristics, such as e.g., their sex or age. These barriers, limit an adult's options for lifelong learning.

The effect of gender on body shame was a main finding from this study. The unattractiveness considered that produces shame and loss of interest and pride about our own bodies (Lewis, 2003). According to Gilbert (2005), factors that connect and enhance the feeling of shame include the stress of social interaction, a higher sense of inferiority, a perception of lower social power and a tendency to view oneself less favorably than others. Adult learners experience all these factors. A correlation has been found between marital status and characterological shame, where unmarried, divorced and widowed were more affected that single persons. This point vividly illustrates the impact of social context and environmental conditions on how we react with shame and separates it from the shame we feel due to our innate performance and personality. The study of Leeming and Boyle (2004) also points out this distinction between the effects personal and social factors on experiencing shame.

Our findings align with previous theory and research that has shown that single and employed individuals are less predisposed to development of depression when to married and unemployed persons (Crepet, 1993; Prince, 1999; Pugliesi, 2009; McLaughlin, 2010). Information on these relationships is critical to improving the learning process since depression can affect motivation for learning and an individual's problem-solving efficacy (Lazarus, 1991). Additionally, depression influences how a person manages previous failures and avoids new one failures (Andrews, 2009).

The results of this study also agree with existing published works regarding the anxiety experienced by unemployed and married adults (Bartley, 1994; Lahelma, 1992; Ross, 1995; Wishman, 1999; Scott, 2010). Extensive research has been done on the prevalence of anxiety in educational institutions where anxiety has been found to have a negative effect on academic achievement (Zeidner, 2014). 
In Adult Education, learning processes are hampered by psychological barriers faced by adults due to their self-perception and possibly by their own doubts about the environment in which they live. Adults' motivations and aspirations change with time and such psychological barriers can make it difficult for them to participate in educational processes (European Commission, 2012). In the educational conceptual framework, detection of negative emotions is very important and thus it has been linked to learners' assessment, satisfaction and learning performance (Rowe, 2014; Pekrun, 2014). Comprehending such emotions can help develop theoretical and practical strategies to optimizate educational processes (Rowe, 2018). Recognizing the diversity of obstacles faced by learners can help advance of appropriate educational methods that are not only adapted to individual needs but are also used to select appropriate training interventions. Any actions that can facilitate understanding of individual needs, characteristics and situations of lifelong learners can improve their access to learning opportunities throughout their lives.

The present study highlighted internal variables that could be related to adults' learning activities. There is a need to overcome barriers to Adult Education to make it feasible and sustainable for all learners regardless of their existent social needs.

\section{Strengths and Limitations}

The present study looked into the impact of psychological factors on educational process of vulnerable adult learners. The strengths of the research include the use of discreet and in-depth methods to obtain personal information that may affect one's decision to join a school, and his or her entire school attendance.

There were some limitations. The number of the participants was relatively small, and questionnaires were distributed in only 2 schools in Greece. It is possible the results of this study may not be generalizable to all the SCSs students in the Greek territory.

\section{Acknowledgments}

No external funding spurces were used to complete this research.

\section{References}

Adler, N. E., Thomas, B., Margaret, A. C., Sheldon, C., Susan, F., Robert, L. K., \& Leonard, S. (1994). Socioeconomic Status and Health; The Challenge of the Gradient. American Psychologist, 49, 15-24. https://doi.org/10.1037/0003-066X.49.1.15

American Psychiatric Association. (2013). Diagnostic and Statistical Manual of Mental Disorders (5th ed.). DSM-5, American Psychiatric Publishing. https://doi.org/10.1176/appi.books.9780890425596

Andrews, B., \& Hunter, E. (1997). Shame, early abuse and course of depression in a clinical sample: A preliminary study. Cognition and Emotion, 11, 373-381. https://doi.org/10.1080/026999397379845

Andrews, B., Qian, M., \& Valentine, J. D. (2002). Predicting depressive symptoms with a new measure of shame: The experience of Shame Scale. British Journal of Clinical Psychology, 41(1), 29-42. https://doi.org/10.1348/014466502163778

Andrews, G., Henderson, S., \& Hall, W. (2001). Prevalence, comorbidity, disability and service utilization. Overview of the Australian National Mental Health Survey. British Journal of Psychiatry, 178, 145-153. https://doi.org/10.1192/bjp.178.2.145

Andrews, P. W. \& Thomson, J. A. (2009). The bright side of being blue: Depression as an adaptation for analyzing complex problems. Psychological Review, 116, 620-654. https://doi.org/10.1037/a0016242

Apple, M. W. (2004). Ideology and curriculum (2nd ed.). New York, London: Routledge. https://doi.org/10.4324/9780203487563

Arico, F., \& Lasselle, L. (2010). Enhancing interns' aspirations towards the labour market through skill acquisition: The Second Chance Schools experience. Sire Discussion Paper (56). Scottish Institute for Research in Economics. Retrieved from https://econpapers.repec.org/paper/ednsirdps/651.htm

Asimaki, A., Kiriazopoulou, E., \& Vergidis, D. (2016). The contribution of Second Chance Schools to the symbolic capital of the trainees. Hellenic Journal of Research in Education, 5(1), 76-89.

Atif, K., Khan, H. U., Ullah, M. Z., Shah, F. S., \& Latif, A. (2016). Prevalence of Anxiety and Depression Among Doctors: The Unscreened and Undiagnosed Clientele in Lahore, Pakistan, Pakistan Journal of Medical Sciences, 32(2), 294-298.

Bartley, M. J. (1994). Unemployment and ill health: understanding the relationship. Journal of Epidemiology Community Health, 48, 333-37. https://doi.org/10.1136/jech.48.4.333 
Bjelland, I., Krokstad, S., Mykletun, A., Dahl, A. A., Tell, G. S., \& Tambs, K. (2008). Does a higher educational level protect against anxiety and depression? The HUNT study. Social Science \& Medicine, 66(6), 1334-1345. https://doi.org/10.1016/j.socscimed.2007.12.019

Bosma, H., Brandts, L., Simons, A., Groffen, D., \&Akker, M. (2014). Low socioeconomic status and perceptions of social inadequacy and shame: findings from the Dutch SMILE study. European Journal of Public Health, 25(2), 311-313. https://doi.org/10.1093/eurpub/cku212

Bowman, H., \& Burden, T. (2002). Ageing, community adult education, and training. Education and Ageing, 2(3), 147-167. ISSN-1352-8580. Retrieved from https://eric.ed.gov/?id=EJ678550

Cameron, I. M., Crawford, J. R., Lawton, K., et al (2008). Psychometric comparison of PHQ-9 and HADS for measuring depression severity in primary care. British Journal of General Practice, 58(546), 32-36. https://doi.org/10.3399/bjgp08X263794

Crepet, P., Piazzi, A., Vetrone, G., \& Costa, M. (1993). Effects of occupational status on the mental health of young Italian men and women. A cross-sectional study. International Journal of Social Psychiatry, 39(4), 303-312. https://doi.org/10.1177/002076409303900406

Cross, P. (1981). Adults as learners: increasing participation and facilitating learning. San Francisco: Jossey-Bass. Retrieved from https://eric.ed.gov/?id=ED200099

Dohrenwend, B. P., Itzhak, L., Patrick, S., Sharon, S., Guedalia, N., Bruce, L., ... Ann, S. (1992). Socioeconomic Status and Psychiatric Disorders: The Causation-Selection Issue. Science, 255, 946-952. https://doi.org/10.1126/science.1546291

European Commission. (1996). White Paper on Education and Training, Teaching and Learning. Towards the knowledge society.Luxembourg: Office for Official Publications of the European Communities. Retrieved from https://op.europa.eu/el/publication-detail/-/publication/d0a8aa7a-5311-4eee-904c-98fa541108d8/language-en

European Commission. (2001). Second Chance Schools: The results of a European pilot project. Retrieved from http://www.e2oespana.org/wp-content/uploads/2016/06/Report_E2C-Schools_pilot_project.pdf

Gilbert, P., Boxall, M., Cheung, M., \& Irons, C. (2005). The relation of paranoid ideation and social anxiety in a mixed clinical population. Clinical Psychology and Psychotherapy, 12, 124-133. https://doi.org/10.1002/cpp.438

Glaroudi, A., \& Katsani, G. (2008). The need to design a skills development model through the experience of Counseling Careers in Second Chance Schools. Retrieved from https://repository.edulll.gr/edull1/retrieve/782/138.pdf

Government Gazette 1861/2014.

GovernmentGazette 188/1997.

Greene, J., Cohen, D., Siskowski, C., \& Toyinbo, P. (2017). The relationship between family caregiving and the mental health of emerging young adult caregivers. The Journal of Behavioral Health Services \& Research,44(4), 551-5663. https://doi.org/10.1007/s11414-016-9526-7

Holzer, C. E., Brent M. S., Jeffrey W. S., Philip J. L., Jerome K. M., Linda, G., Myrna, W., \& Phillip, B. (1986).The Increased Risk for Specific Psychiatric Disorders among Persons of Low Socioeconomic Status. American Journal of Social Psychiatry, 6, 259-671. Retrieved from https://psycnet.apa.org/record/1988-07601-001

Horwitz, A. V. (2013). Anxiety: A short history. Baltimore: The Johns Hopkins University Press.

Karekla, M., Pilipenko, N., Feldman, J. (2012). Patient Health Questionnaire: Greek language validation and subscale factor structure. Comprehensive Psychiatry, 53(8), 1217-1226. https://doi.org/10.1016/j.comppsych.2012.05.008

Kasworm, C. E., Rose, A. D., \& Ross-Gordon, J. M. (2010). Handbook of adult and continuing education. United Kingdom: Sage Publications.

Kemeny, M. E., Gruenewald, T. L., \& Dickerson, S. S. (2004). Shame as the emotional response to threat to the social self: Implications for behavior, physiology, and health. Psychological Inquiry, 15(2), 153-160. Retrieved from https://psycnet.apa.org/record/2004-17286-007

Kessler, R. C., Chiu, W. T., Demler, O., Merikangas, K. R., \& Walters, E. E. (2005). Prevalence Severity, and Comorbidity of 12-month DSM-IV Disorders in the National Comorbidity Survey Replication. Archives of General Psychiatry, 62, 617-27. https://doi.org/10.1001/archpsyc.62.6.617

Kokkos, A. (2005). Adult Education Methodology: Theoretical Framework and Learning Conditions, volume A. Patra: HOU. 
Kokkos, A. (2017). Transformation of dysfunctional perceptions: Teaching method for school and adult education. Scientific Association of Adult Education. Adult Education, 39, 47-51.

Kump, S., \& Krasovec, S. J. (2007). Education: A possibility for empowering older adults. International Journal of Lifelong Education, 26(6), 635-649. https://doi.org/10.1080/02601370701711331

Lahelma, E. (1992). Paid employment, unemployment and mental well-being. Psychiatria Fennica, 23, $131-44$. Retrieved from https://psycnet.apa.org/record/1993-23695-001.

Lazarus, R. S. (1991). Emotion and Adaptation. New York, UK: Oxford University Press.

Lecrubier, Y. (2001). Improved Ability to Identify Symptoms of Major Depressive Disorder (MDD) in General Practice. International Journal of Psychiatry Clinical Practice, 5(1), 3-10. https://doi.org/10.1080/13651500152048397

Leeming, D., \& Boyle, M. (2004). Shame as a social phenomenon: A critical analysis of the concept of dispositional shame. Psychology and Psychotherapy. Theory, Research and Practice, 77, 375- 396. https://doi.org/10.1348/1476083041839312

Leve, L. G. (2001). Between Jesse Helms and Ram Bahadur: Participation and empowerment in women's literacy programming in Nepal. Political and Legal Anthropology Review, 24(1), 108-28. https://doi.org/10.1525/pol.2001.24.1.108

Lewis, M. (1971).Shame and Guilt in Neurosis. New York: International Universities Press.

Lewis, M. (2003).The role of the self in shame. Social Research, 70(4), 1181-1204.

Margara, T., \& Anagnou, E. (2008). Second Chance Schools in Adult Education: A Comparative Approach to Greece, Denmark, France. Available at https://repository.edulll.gr/edulll/retrieve/782/138.pdf, Access in 2/10/2019.

Marmarinos, I., Sakellari, M., \& Tzoumaka, E. (2008).Staff professional development team at the Second Chance School (SDE) of Peristeri.Available at https://repository.edulll.gr/edulll/retrieve/782/138.pdf, Access in 2/10/2019.

McLaughlin, D., Vagenas, D., Pachana, N.B., \& Dobson, A. (2010).Gender differences in social network size and satisfaction in adults in their 70s.Journal of Health Psychology, 15, 671-679. https://doi.org/10.1177/1359105310368177

Mezirow, J. (1991). Transformative dimensions of adult learning. San Francisco: Jossey-Bass.

Miech, R. A., \& Shanahan, M. J. (2000). Socioeconomic status and depression over the life course. Journal of Health and Social Behavior, 41(2), 162-176. https://doi.org/10.2307/2676303

Miech, R. A., Caspi, A., Moffitt, T. E., Wright, B. R. E., \& Silva, P. A. (1999). Low socioeconomic status and mental disorders: a longitudinal study of selection and causation during young adulthood. The American Journal of Sociology, 104, 1096-1131. https://doi.org/10.1086/210137

Mills, R. S. L. (2005). Taking stock of the developmental literature on shame. Developmental Review, $25(1), 26-63$. https://doi.org/10.1016/j.dr.2004.08.001

Munns, G., \& McFadden, M. (2000). First chance, second chance or last chance? Resistance and response to education, British Journal of Sociology of Education, 1(21), 59- 76. https://doi.org/10.1080/01425690095162

Ouzouni, C., \& Nakakis, K. (2011). The reliability and validity of measurement tools in quantitative studies. Nursing, 50(2), 231-239. $\quad$ Retrieved from https://www.researchgate.net/publication/289292707 _Validity_and_Reliability_of_Measurement_Instruments_in_Quantitative_Studies.

Papaioannou, E., \& Gravani, M. N. (2018). Empowering vulnerable adults through second-change education: A case study from Cyprus. International Journal of Lifelong Education, 37(4), 435-450. https://doi.org/10.1080/02601370.2018.1498140

Pekrun, R., Cusack, A., Murayama, K., Elliot, A. J., \& Thomas, K. (2014). The power of anticipated feedback: Effects on students' achievement goals and achievement emotions. Learning and Instruction, $29,115-124$. https://doi.org/10.1016/j.learninstruc.2013.09.002

Prince, M. J., Beekman, A. T. F., Deeg, D. J. H., Fuhrer, R., Kivela, S. L., Lawlor, B. A., ... Copeland, J. R. M. (1999). Depression symptoms in late life assessed using the EURO-D scale. Effect of age, gender and marital status in 14 European centres. British Journal of Psychiatry, 174, 339-345. https://doi.org/10.1192/bjp.174.4.339

Prins, E. (2008). Adult literacy education, gender equity and empowerment: Insights from a Freirean-inspired literacy programme. Studies in the Education of Adults, 40(1), 24-39. https://doi.org/10.1080/02660830.2008.11661554

Pugliesi, K., \& Shook, S. (2009). Gender, ethnicity and network characteristics: variation in social support resources. Sex 
Roles, 38, 215-238. https://doi.org/10.1023/A:1018733116398

Quilty, L. C., Van Ameringen, M., Mancini, C., Oakman, J., \& Farvolden, P. (2003). Quality of Life and the Anxiety Disorders. Journal of Anxiety Disorder, 17, 405-426. https://doi.org/10.1016/S0887-6185(02)00225-6

Ross, C. E., \& Mirowsky, J. (1995). Does employment affect health? Journal of Health and Social Behavior, 36, 230-43. https://doi.org/10.2307/2137340

Ross, S., \& Gray, J. (2005). Transition and re-engagement through Second Chance Education. The Australian Educational Researcher, 32(3), 103-140. https://doi.org/10.1007/BF03216829

Rowe A. D., \& Fitness, J. (2018). Understanding the Role of Negative Emotions in Adult Learning and Achievement: A Social Functional Perspective. Behavioral Sciences, 8, 27.https://doi.org/10.3390/bs8020027

Rowe, A., Fitness, J., \& Wood, L. (2014). The role and functionality of emotions in feedback at university: A qualitative study. The Australian Educational Researcher, 41, 283-309. https://doi.org/10.1007/s13384-013-0135-7

Scott, K. M., Wells, E. J., Angermeyer, M., Brugha, T. S., Bromet, E., Demyttenaere, K., ... Kessler, R. C. (2010). Gender and the relationship between marital status and first onset of mood, anxiety and substance use disorders. Psychological Medicine, 40(9), 1495-1505. https://doi.org/10.1017/S0033291709991942

Smyth, J., \& Hattam, R. (2004). 'Dropping Out', Drifting Off, Being Excluded: Becoming somebody without school. New York: Peter Lang Publishing Inc.

Spielberger, C. D., Gorsuch, R. L., Lushene, R., Vagg, P. R., \& Jacobs, G. A. (1983). Manual for the State-Trait Anxiety Inventory. Palo Alto, CA: Consulting Psychologists Press.

Spitzer, R. L., Williams, J. B. W., \& Kroenke, K. et al. (1994). Utility of a new procedure for diagnosing mental disorders in primary care: the PRIME-MD 1000 study. JAMA, 272, 1749-1756. https://doi.org/10.1001/jama.1994.03520220043029

Stoilescu, D., \& Carapanait, C. (2011). Renegotiating relations among teacher, community and students. European Education, 43(2), 54-73. https://doi.org/10.2753/EUE1056-4934430203

Tangney, J. P., \& Dearing, R. L. (2002). Emotions and social behavior. Shame and guilt. Guilford Press.

TeRiele, K. (2000). The Best Thing I've Ever Done: Second chance education for early school leavers. AARE Conference, University of Sydney. Retrieved from https://www.aare.edu.au/data/publications/2000/ter00203.pdf

Ugalde, A., Krishnasamy, M., \& Schofield, P. (2014). The relationship between self-efficacy and anxiety and general distress in caregivers of people with advanced cancer. Journal of PalliativeMedicine, 17(8), 939-41. https://doi.org/10.1089/jpm.2013.0338

Unesco. (1997). Adult education: the Hamburg Declaration; the agenda for the future. Retrieved from https://uil.unesco.org/adult-education/confintea/adult-education-hamburg-declaration-agenda-future, Access in 20/11/2020.

Vergidis, D. (2003). Adult education. Contribution in the specialization of executives and trainers. Athens: Greek Letters.

Vergidis, D., \& Prokou, E. (2005). Design, administration, evaluation of adult education programs. Elements of socio-economic operation and institutional framework. Volume A. Patra: EAP.

Vergidis, D., Eystratoglou, A., \& Nikolopoulou, B. (2007). Second Chance Schools: Innovative Elements, Problems and Perspectives. Adult Education, 12, 25-26.

Vergidou, A., Vergidis, D., \& Ifanti, A. (2018). Second Chance Schools: Educational Innovations and School Culture. Play or adapt? Educational Sciences, 2, 169-186. Retrieved from https://docplayer.gr/116258130-Second-chance-schools-adult-education-educational-innovation-school-culture.htm 1.

Wishman, M. A., \& Bruce, M. L. (1999). Marital dissatisfaction and incidence of major depressive episode in a community sample. Journal of Abnormal Psychology, 108, 674-678. https://doi.org/10.1037/0021-843X.108.4.674

World Health Organization (2020). Depression. Retrieved from https://www.who.int/news-room/fact-sheets/detail/depression. Access in 15/12/2020

Wyn, J., Stokes, H., \& Tyler, D. (2004). Stepping Stones: TAFE and ACE program development for early school leavers, NCVER. Retrieved from https://www.ncver.edu.au/research-and-statistics/publications/all-publications/stepping-stones-tafe-and-ace-progra 
m-development-for-early-school-leavers, Access in 1/10/2019

Zeidner, M. (2014). Anxiety in education. In P. A., Alexander, P., Pekrun, \& L. Linnenbrink-Garcia, (Eds.), International Handbook of Emotions in Education, pp. 265-288. London, UK: Routledge.

Mezirow, J. (2007). Transformational Learning. Athens: Metaixmio.

\section{Appendix}

Table 1. Cronbach's Alpha in the Experience of Shame Scale-ESS)

\begin{tabular}{|l|l|}
\hline Cronbach's Alpha & N of Items \\
\hline 0,808 & 4 \\
\hline
\end{tabular}

Table 2. Cronbach's Alpha in the Spielberger's State Trait Anxiety Inventory

\begin{tabular}{|l|l|}
\hline Cronbach's Alpha & N of Items \\
\hline 0,889 & 3 \\
\hline
\end{tabular}

Table 3. Cronbach's Alpha in the Patient Health Questionnaire-9 (PHQ-9)

\begin{tabular}{|l|l|}
\hline Cronbach's Alpha & N of Items \\
\hline 0,853 & 9 \\
\hline
\end{tabular}

Table 4. Demographics of participants

\begin{tabular}{lcc}
\hline Demographics & Frequency & Percentage \\
\hline Sex & 49 & \\
Male & 46 & 41,6 \\
Female & 95 & 100,00 \\
Total & & \\
Age & 36 & 37,9 \\
$18-34$ & 47 & 49,5 \\
$35-50$ & 12 & 12,6 \\
$50+$ & 95 & 100,00 \\
Total & & \\
Marital Status & 51 & 53,7 \\
Married with children & 8 & 8,4 \\
Married without children & 12 & 12,6 \\
Divorced & 3 & 3,2 \\
Widower & 21 & 22,1 \\
Unmarried & 95 & 100,00 \\
Total & & \\
Professional Status & 40 & 42,1 \\
Unemployed & 10 & 10,5 \\
Employed in public sector & 36 & 37,9 \\
Employed in private sector & 6 & 6,3 \\
Retired & 3 & 3,2 \\
Unable to work & $\mathbf{9 5}$ & $\mathbf{1 0 0 , 0 0}$ \\
\hline Total & &
\end{tabular}


Table 5. Value range, Average, Standard deviation and mean value on the Experience of Shame Scale (ESS)

\begin{tabular}{l|llll}
\hline \multicolumn{2}{c}{ Value Range } & Average & $\begin{array}{l}\text { Standard } \\
\text { Deviation }\end{array}$ & Mean Value \\
\hline Characterological Shame & $10-38$ & 18,31 & 5,43 & 18 \\
Behavioral Shame & & & & \\
Bodily Shame & $7-27$ & 16,6 & 4,59 & 16 \\
Total score & $2-12$ & 5,73 & 1,91 & 5 \\
\hline
\end{tabular}

Table 6. Correlations identified in the Experience of Shame Scale-ESS

\begin{tabular}{l|lc}
\hline Correlation & \multicolumn{1}{l}{ r } & Significance level \\
\hline Sex and Body shame & 0,27 & 0,01 \\
Marital Status and Shame & $-0,21$ & 0,05 \\
Marital Status and Characterological Shame & $-0,21$ & 0,05 \\
\hline
\end{tabular}

Table 7. Price range, Average, Standard deviation and mean for the Patient Health Questionnaire-9 (PHQ-9)

\begin{tabular}{l|llll}
\hline & Price Range & Average & $\begin{array}{l}\text { Standard } \\
\text { Deviation }\end{array}$ & Mean Value \\
\hline Total Score & $0-15$ & 5,87 & 4,16 & 6 \\
\hline
\end{tabular}

Table 8. Correlations identified in the Patient Health Questionnaire-9 (PHQ-9)

\begin{tabular}{l|lc|}
\hline Correlation & r & Significance level \\
\hline Depression and marital status & $-0,24$ & 0,05 \\
Depression and professional status & $-0,23$ & 0,05 \\
\hline
\end{tabular}

Table 9. Price range, Average, Standard deviation and mean for the Spielberger State Trait Anxiety Inventory

\begin{tabular}{|c|c|c|c|c|}
\hline & Price Range & Average & $\begin{array}{l}\text { Standard } \\
\text { Deviation }\end{array}$ & Mean Value \\
\hline State Anxiety & $23-74$ & 44,53 & 12,37 & 45 \\
\hline Trait Anxiety & $21-60$ & 38,85 & 10,2 & 38 \\
\hline Total Score & $44-123$ & 83,41 & 20,24 & 84 \\
\hline
\end{tabular}

Table 10. Correlations identified in the State Trait Anxiety Inventory

\begin{tabular}{l|lc}
\hline Correlation & \multicolumn{1}{l}{ r } & Significance Level \\
\hline Transient stress and marital status & $-0,26$ & 0,05 \\
Permanent stress and marital status & $-0,26$ & 0,05 \\
Total stress and marital status & $-0,28$ & 0,01 \\
Permanent stress and professional status & $-0,25$ & 0,05 \\
Total stress and professional status & $-0,23$ & 0,05 \\
\hline
\end{tabular}




\section{Copyrights}

Copyright for this article is retained by the author(s), with first publication rights granted to the journal.

This is an open-access article distributed under the terms and conditions of the Creative Commons Attribution license (http://creativecommons.org/licenses/by/4.0/). 